\title{
Bearing witness: The burden of individual responsibility and the rule of law
}

\begin{abstract}
When humans are caught up in systems that inflict great suffering upon them, people of conscience have a responsibility to bear witness and those having privileges and mandates should offer solidarity and engage in practical action. This paper focusses on the ethical public responsibility of witnessbearing as the uncomfortable and provoking response to such suffering. It discusses the influence of narratives, images, photography, media and the arts, reports and reflects personal experiences as an important element of knowledge, and makes the case for actively bearing witness and expressing solidarity.
\end{abstract}

\section{Introduction}

\begin{abstract}
It was when I called my family at home and described kneeling on the floor in the church, which now stands in the middle of a rased, bulldozed, mud bath of rubbish and devastation, that the tears came. The sound of the bulldozers coming ever closer, the presence of the bodies draped in the white Eritrean shawls (suria) at prayer beside me, the juxtaposition of the silent petitions of hope and peace alongside the violence of destruction and hopelessness were too much for the words which tried and failed to describe the scene. Witnessing became the witness of tears.
\end{abstract}

Since the 'reception crisis' more popularly known as the 'refugee crisis' began in Europe, there have been many different fact-finding missions. These have been visits to demonstrate solidarity and concern and humanitarian ventures to the flashpoints on the borders of Europe and also the border between France and the UK in Calais. There have also been visits designed to threaten and deter migrants and refugees as well as parachute visits, which allow for photo opportunities. A sustained series of visits from humanitarians and people in the public eye have enabled the situations in Calais, Lesvos, and Lampadusa to become a matter of public concern after years of obscurity.

At times of acute concern, and in the face of collapsing systems of justice and law in the European Union, where binding obligations are being set aside by states and local government in favour of security and emergency measures, the space for meaningful action is diminished.

Since 2016, UNHCR and Médecins sans frontières (MSF) have pulled out of working in 'reception' facilities in Greece in protest at the policies of refoulement 
on the part of the European Union. Boats in the Mediterranean are being intercepted and turned back to Libya, where there are accurate witness reports of refugees being sold into slavery. Humanitarian actors are increasingly under threat of criminalisation and in need of legal protection, and witnesses to their intentions and their actions both on the seas and on land. A large worldwide movement has developed of people of conscience working as allies in various points of both acute need and reception. Most importantly those seeking protection and refuge have themselves made demands for their own rights under international law against the closing of borders and for decent conditions in reception centres.

Within this movement there has been substantial critical commentary. Humanitarian actors have been cast as naïve, or as 'white saviours' or overly charitable in intent; as diminishing refugee agency or as ineffectual, through to threats to state and European security. Large NGOs have struggled to respond quickly to what have been situations of acute humanitarian need for aid. Conditions within Europe's borders have been worse than in many areas of the world, where camp construction and reception facilities have had a much longer history. Politicians have been seen to both engage and abdicate responsibility.

In 2016, I was part of co-designing a visit which aimed to bear witness, rather than 'finding facts', in Calais, and to do so in such a way that was not about jumping to political conclusions, but developing and sustaining relationships with actors on the ground. This visit included a range of Scottish National Party Members of Parliament from the Home Affairs select committee, and academics, clinicians, campaigners, and those who have long experience in working with refugees in Scotland. These latter are all expert witnesses and experts at witnessing.

At times of chronic humanitarian crisis an active approach is that of bearing witness. Throughout the South African Apartheid years, courts, media, academic research, creative artworks, and government chambers provided spaces for bearing witness to the ways in which justice was undermined and human rights were violated, revealing publicly the structures at work to systematically destroy Black lives and undermine forms of resistance. Each domain was able to bear witness in distinctly different ways.

In Newton's laws of motion, the third law states that when one body exerts a force on a second body, the second body simultaneously exerts a force equal in magnitude and opposite in direction on the first body. In the struggles for migration justice and to honour the articles in the Refugee Convention and European Convention on Human Rights, there is indeed a sense in which the present situation is metaphorically caught in a struggle for and of motion, fraught with visceral emotion. The Refugees Welcome movement has been met with a rise of national populism, which is marked in particular by varieties of xenophobia and white 
supremacy, and with European measures to invest far greater sums in the Frontex operations on the borders than in the humanitarian aid, though some aid has been granted. Here we have pitted against each other agencies and populations determined to fix borders, stop movement, close exits, and others wishing to open the borders, free the movement, let movement flow. Within this metaphorical impasse, agency is exerted across the force field, and with it the act of witnessing has come to the fore.

\section{Witness-bearing}

Visits to situations of conflict and chronic humanitarian need have occurred in various situations in recent years. During the Decade to Overcome Violence, the World Council of Churches organised visits to bear witness to the suffering of peoples in Palestine-Israel, Nigeria, Sierra Leone, Liberia, Sri Lanka, and Indonesia, among others. ${ }^{1}$ The visitors included those skilled in observation, writing, reporting, legal understanding, research, poetic practice, and medical knowledge, who had as part of their professional practice the ability to document and reveal something of the suffering with credibility and understanding.

In the context of Calais there has been an extraordinary mobilization of humanitarian aid from the UK, and especially from Scotland, with community groups leading where larger NGOs have been slow to follow and where local governments and states have failed to protect life and dignity. In addition, politicians and human rights celebrities have engaged in awareness raising and solidarity visits, which have highlighted the situation, and the BBC held 'Songs of Praise' from the Calais church during the summer of 2015.

Meanwhile MSF and Damien Carême, maire of Grande-Synthe, began the process of building a camp in the Calais area after the failure of the state and the local prefecture to act in accordance with their obligations. This was done for a fraction of the cost of the container detention camp put in place by state authorities under duress in Calais, and was done so non-violently and with a remarkably intelligent and striking approach which is distinctive and deserves the acclaim and interest it is beginning to attract, even in these first three weeks. The presence of the camps in the Calais/Grande-Synthe areas represented contested space for the state, the local administration, and for local residents as well as for the UK.

1 See http://www.overcomingviolence.org/en/peace-convocation/preparatory-process/livingletters-visits.html. 
At times of great human suffering we see extraordinary courage and compassion. Communities across Scotland, and Europe more widely, have led with creativity, practical action, and costly generosity in Calais, Lesvos, and in receiving communities. In this there have been multiple acts of individuals taking responsibility and making a range of changes to their lives. Repeatedly, in the work I undertake with the UNESCO Chair Programme at the University of Glasgow I now hear discussions and presentations from individuals who begin by saying, "In September 2015, I...” The publication of the photograph of Aylan Kurdi, the Kurdish refugee boy drowned and washed up on a Turkish beach, was of such poignancy that it literally changed the course of individual responsibility in such large numbers it became the collective movement of welcoming refugees.

The generosity of these individuals is equalled and exceeded by that of those who are themselves seeking refuge, though it is also different. The communities of solidarity within those forced to migrate receive little attention, but are predominantly how and where assistance is found. Within national and ethnic groups of refugees, those from the same towns or local communities, those with similar experiences on the journey of detention, or hiding, or crossing land and seas borders, new clusters of solidarity grow around shared experiences and the responsibilities those seeking refuge take for those around them in their immediate families, but also in circles of solidarity and mutual support born of geography as much as kinship, and forged in extremis. The people have led where larger institutions and some governments have been slow, reluctant, and mired in outdated thinking and ineffective solutions.

At the same time, we have witnessed a vicious rise in xenophobia and structural violence against migration of all forms. This has happened in Europe before, and we have much to learn from the lessons of history. The last time Europe faced such numbers of refugees it failed (Arendt 1943). Facing its failure, the articles protecting human rights were created and these very articles are now in peril. The last time the people of Europe said never again. Bearing witness to this historical moment has become action in the present day. While the ending of the Second World War was a different historical moment and set of material circumstances to those of the present day and is by a long way not structurally or materially the same as the present moment in Europe, the symbolism of that moment in history and the creation of an ethic - particularly in Europe, and across humanitarian action - of witnessing and voicing solidarity has come to determine action, new ethical responsibilities, and how they are framed within the polity, particularly within groups of individuals.

Restatement of the moral code within the Refugees Welcome movement, and among the refugee actors themselves, runs as follows: when human beings are caught up in systems which inflict great suffering upon them, people of con- 
science have a responsibility to bear witness. When homes, livelihoods, dignity, and lives are destroyed, those of us with privilege and mandates should offer solidarity, practical action, and learn from those with direct experience, rather than relying on second-hand assumptions. There has been a great deal of voicing of solidarity since 2015. Much of it through media and the arts, public demonstrations, humanitarian endeavours, refugee-led agency, reluctant political change under a variety of pressures, legal actions, and non-violent direct action. In and of itself it represents the international, multilingual, and cultural work of bearing witness (Phipps 2017).

There is considerable technical academic work on the idea of the witness and of testimony in legal theory and jurisprudence (Scarry 2010; Choo 2015; Dennis 2017). There is not space in this chapter to go into this literature in detail. Instead, I wish to draw on the metaphorical power of the idea of witness-bearing as an action which expands on the idea of a visit or trip. Witness-bearing is not the same as visiting as it can occur in conditions which are not necessarily proximate. In her Nobel lecture, Judith Butler (2011) differentiates between actions responding ethically to suffering at a distance, and those which are proximate:

The two questions that concern me are at first quite different from one another. The first is whether any of us have the capacity or inclination to respond ethically to suffering at a distance, and what makes that ethical encounter possible, when it does take place. The second is what it means for our ethical obligations when we are up against another person or group, find ourselves invariably joined to those we never chose.

This distinction is pertinent to teasing out the significance of witness-bearing as a response to suffering. In law the witness is usually in a proximate position, and it is often by chance that they are called up to offer, as an ethical civic duty, their best version of what they saw or experienced. The role of the witness is crucial to the work of justice, in the sense of the judgements of the law. But such an ethical obligation writes itself across the landscape of the Refugees Welcome movement as this same witnessing to images on screen, writings in newspapers, and artworks poses the same questions 'Will you bear witness? Will you use your body, time, intellect, memory, speech, writing, and actions to serve the rule of justice, the common good, the rights of humanity? To do this in the legal setting is especially codified. To do this in the polity takes many forms, but is still undergirded by a sense of ethical responsibility. This ethical responsibility may also, it should be noted, be found in the structures of feeling common to individuals or groups protesting ethnic diversity bearing witness, however erroneously, as they do, to a sense of injustice against their own moral codes of ethnic purity.

Given the power unleased by the publication of the photograph of Aylan Kurdi - mentioned above as the defining moment in the narratives of individual 
responsibility in action for refugee justice - it is worth reflecting on the role played by artistry and photography in particular. Through the shared experience of the image in provoking the wave of responses as the image was seen and shared by millions worldwide. The question, 'Will you bear witness?' began to be answered by individuals, and individuals forming new collectives, in myriad ways. In a piece for the art journal Drouth, I reflect on this as follows:

\begin{abstract}
Photography is a form which intervenes in such situations in ways which have teased philosophers of the twentieth and twenty-first century. Susan Sontag has written of the ways photographers approach the question of the 'quintessential' experience of modernity, that of 'Being a spectator of calamities taking place in another country.' Her approach to the question as to what it means to be human, and a spectator of calamities is to separate out, not feeling from reason, but rather the act of bearing witness and the acts of artistry.

"For photography of atrocity, people want the weight of witnessing without the taint of artistry, which is equated with insincerity or mere contrivance.” (Sontag 2004, 26-27)
\end{abstract}

Sontag has also considered the way the camera itself, with its interventions on time with an image bound to fade, works with different temporal frames to that of words: 'A narrative seems likely to be more effective than an image. Partly it is a question of the length of time one is obliged to look, to feel' (Sontag 2004, 110).

While there is a difference in modes of witnessing and the place or otherwise of artistry in forms of witnessing, it is the metaphor of witness-bearing that is the idea of bearing which interests me here, that the working of witnessing, if chosen, must be borne, as an ethical public responsibility in the context of people seeking refuge. This means that the metaphor meets artistry and the work of bearing witness takes on a load, as individual responsibility which is borne, struggled under, which has weight. Donna Haraway (2016), in Staying with the Trouble, asks:

How can we think in times of urgencies without the self-indulgent and self-fulfilling myths of apocalypse, when every fibre of our being is interlaced, even complicit, in the webs of processes that must somehow be engaged and repatterned? ${ }^{2}$

Feminist theologian Sallie McFague equally has written of metaphors as follows:

Metaphor is, for human beings, what instinctual groping is for the rest of the universe - the power of getting from here to there. The imagination is the chief mover, setting the familiar in an unfamiliar context, so that new possibilities can be glimpsed. Metaphorical thinking

2 I'm indebted to Sarah Thomas for introducing me to Haraway's critical work on the Anthropocene and Le Guin's idea of 'rebearing' through her PhD research. 
is the way human beings - selves not mere minds - move in all areas of discovery. (McFague 1975)

Bearing witness is both a present-time activity and an activity of memory. It changes those who are witnesses, often profoundly, as others who have made such visits will testify. The heaviness of witnessing to the erosion of and refusal of the rights of refugees weighs heavily in the polity and leads to individual actions which are outside of the ordinary, from opening up homes, to providing humanitarian assistance, to deliberately reorientating friendship groups around greater inclusion, to acts which border on and may well be illegal, but are seen as upholding natural justice. In this, individuals demonstrate a form of stoicism, a need not to flinch from the heaviness, the acute discomfort, even anger and helplessness, of witnessing to what, wittingly or unwittingly, our policies and voting habits, foreign and domestic, have done. Individuals weigh the questions of right and wrong for themselves, bear the weight of the judgement for themselves and then take on the task, which is invariably costly. Witnesses could be from within the populations of those seeking refuge and often are, and the most powerful testimonies often come from those who are experts by experience. Some testimonies of coming into a witness-bearing role highlight the suddenness of a compulsion to act, others of long being alongside so the witness-bearing is sustained.

\section{Witness-bearing in Calais}

Bearing witness is an uncomfortable and provoking activity. It means being present at the scene of a potential crime, and in Calais, this meant intentionally placing ourselves as a collective in a place where freedom of movement was intentionally frustrated, and where international laws, not to mention laws of motion, were potentially violated. It was to join other actors and witnesses and to offer up our testimony in a variety of ways. Following the visit to the Calais camps these testimonies from the witnesses came through in psychological medical reports, guidance for volunteers, fundraising actions, talks, speeches in Parliament, articles in academic journals (Piacentini 2014), keynote lectures, diary entries, votes, and committee procedures and motions, legal actions, visual documentation (Myers 2016), theoretical observations, and poetry. What follows is my own auto-ethnographic witness report, adapted and published in a national newspaper as a front-page exclusive, just days after the visit, and adapted here. 
Calais, Day 1: Arrived in Calais and had first briefing meeting with SNP MPs from Home Affairs Select Committee and Médecins Sans Frontiers/Help Refugees UK. The catastrophe that is the European failure to uphold its own convention and the binding obligations member states have signed up to unfolds palpably before our eyes. The tenacity of the volunteers, the arrival of the British volunteers when states fail and willing hands are desperately needed, the courage of a local mayor against all the odds, the acute need for legal information and advice, the urgency of trauma support and the woeful inadequacy and failure of imagination for unaccompanied minors.

This is Europe 2016.

Briefings with local NGOs working hard to coordinate and systemise the incredible groundswell of volunteers from Britain immediately following the publication of the photograph of Aylan Kurdi, and the demand from visitors. Being in the presence of activists and veteran warriors in the struggle to manifest compassion is a familiar place. The individuals have qualities which are familiar to ourselves as witnesses, their tenacity, the rapid-fire, well-rehearsed phrases and facts, their clever understanding of the macro and micro politics, their seriousness and humour, their delight in questions which they have found answers of devastating simplicity and honesty, their willingness to share with those with whom they just know they are making common cause.

There is a need to share a great deal of information very quickly. The information is complex and is also important. The politicians ask question after question using every moment of what they are acutely aware is valuable time. Their questions about legal cases, about precedents, about management, about resources, about the humanitarian horrors, about the need to act with dignity and decency and care, and not get in the way of the day-to-day humanitarian and activist work in the camps.

We want to do it this way because it is not about political point-scoring, it is about learning so much on the ground so we can act.

We meet up with a guide from one of the relatively new organisations providing humanitarian assistance, legal education, entertainment, and advocacy in Calais. She is an activist and her habitus repeats as we meet more volunteers and guides. The slender figure is sprung, as if ready for action, emotion is on her face, tiredness is bright in her eyes, as is her readiness for the next task. This is known territory, the territory of work in a time of war. There is such beauty in her statement: 'I wear track suits and no make-up, there isn't time and I'm too tired, but I'm so energized by all of this.'

There is anger and admiration in the speech of those assembled, there is incredulity and an abiding lack of surprise. There is comparison with the work back home. 
And there are the harrowing stories of those known of, those struggling, and of the agonizing injustice which is killing the spirits and killing the bodies and killing the souls.

We, the people of Europe. We did this.

Calais, Day 2: On a stone in the middle of the bulldozed 'Camp Sud' are graffitied the words 'veni, vidi, vici' famously deployed, so history has it, by Caesar after a rapid and complete victory. "I came, I saw, I conquered." So it seems with the 'victory' of the security state with its barbed wire and container-style detention camps, its sterile, lifeless systemising, and the constant activity of bulldozers and diggers uprooting every tree, levelling every dune, steamrolling every tent. I look down into the mud and there is a child's shoe, a boot; a broken pot signs that people were given no chance to empty their homes of belongings. So many shoes - shoes and concentration camps in 2016 Europe, in a country, which should know better. Riot police are patrolling with tear gas, everywhere the vast acreage of $£ 37$ million fences and barbed wire all paid for by the UK taxpayer to keep out the people in the Calais camps.

The people we meet in the Camp Nord are entrepreneurs, cooks, bakers, accountants, professors, geologists, and then there are so many children and young people. They are people on their knees in a small, beautiful sanctified Eritrean church, praying. The people we are keeping from entering the UK greet us with smiles and with greetings of peace, with conversation and gratitude simply for having made the effort to visit them and to bring love and greetings from people back home. The people we keep from the UK with all the razor wire, bulldozing, and fire-raising are people with family who, as luck would have it, live in the UK. The people we keep at bay with tear gas and riot batons have a right to test their claim as having a well-founded fear of persecution, they have a right to a life, under EU law, of dignity and respect.

The people we meet and who are kept at bay by the multi-million pound border industry, which keeps shareholders in dividends, just want to be with their friends and families, as you or I might do. They are from countries with long connections to the UK, to its imperial history, victims of the line-drawing borders on maps a century ago, victims of the way states were not made for the Kurds or the Palestinians. The people in these camps are not those with ready connection of a similar nature to France and its state systems, they are not West African, North African, Chinese - they are indeed the UK's and Europe's responsibility, the result of our actions in history far and near.

There is everywhere a menacing presence of violence, overt and evident - it is the violence of a Europe which has lost its way and is lashing out against the most vulnerable in fear; it is the violence of the state as bully; it is the violence 
sanctioned by our lack of imagination and compassion and humanity; it is the violence which steps in, in place of the articles and declaration made when we said, in Europe, never again. It is 2016. Ecce Homo. We, the people of Europe. We did this.

Calais, Day 2, The Warehouse: I walk into the Warehouse and am met by the very distinctive sights and smells of my childhood - that of the jumble sale. On shelves with neat homemade labels, are piles and piles of clothes and bedding items. All around are volunteers who have come over from Britain. They are overwhelmingly female, student-aged young women and others the ages of their mothers. What brought them is what binds them in the flow of concentrated and good-humoured activity - care and a sense that this is indeed our responsibility to provide basic aid now that the UK and France have failed. On the tables in front of us are orange strips of duct-tape marked up 'Trousers - small, medium, large', 'tops, female; small, medium, large', etc. We get going. It doesn't take long, and cheesy pop music from the 80s is adding to the humour, conversation, and for some of us, nostalgia. Arms, hands, bodies moving almost as in a rhythmic dance sort the clothing into sizes, fold it, place it on the right shelf, and return to the sorting table. There is a murmur of conversation and a lot of laughter over some items. High-value items are sorted separately for different fundraising purposes. There is a tea break, and we sit in the watery sunshine outside sharing hand gel and feel a little overawed by the scale and careful logistics of the whole operation.

It's like an outpost of Britain on French soil. English spoken all around me. It reminds me of the atmosphere in the holiday camps I worked in as a student one summer. Only there is a worry here, and seriousness. Many have not been in to the camps themselves - keen not to get in the way, knowing what they can best do to help and to focus their volunteering on what they have been told needs doing.

The shift finished and we assemble again outside waiting for rides back. The group has formed around a common task, and we are laughing and chatting in between the sober conversations about what we are witnessing and becoming part of. As happens in so many groups where those seeking refuge and those taking up a responsibility where states or large NGOs have failed to act, or at least been slow to act, the formation of what the anthropologist Victor Turner calls 'communitats' - a levelled-out sense of social bond - takes shape (Turner 1995). Later that evening in a cramped room, we push aside chairs and sit on the floor so we can see one another clearly and one by one, in soft tones, or with anger, or with tears, or with bewilderment we tell one another what we have seen. 
Calais, Day 3: On the side of the Mairie in Grande-Synthe - the municipal town council building - there is a banner opposing the Transatlantic Trade Agreement. We sit inside around a table and spend an hour with Maire Carême, the mayor, learning what a difference decisive, ecologically informed, and courageous political leadership can make. The conditions in the camp refugees had set up in woods on the outskirts of Grande-Synthe were 'epouvantable' - 'utterly disgraceful'. When MSF worker Michael Neuman gave a public lecture at the University of Glasgow in February 2016 he said he had never seen such terrible conditions in all his years of missions with MSF, not even in Chechnya. In coalition with MSF and festival organisers, the mayor had used the limited political power he had to move the people out of their miserable conditions and into sheds, which can sleep four people each, giving people the right to cook their own food, decorate the sheds and individualize them, mostly, as it turned out, with political statements about the misery of their conditions or the lamentable situations they had left behind.

We arrive at the new camp, and it's not the riot police approaching us with batons and questions as it was in Calais, but the local gendarmerie - community police - checking our papers, as is normal in France where you have to have your identity card with you at all times. The atmosphere is markedly different. The camp is only three weeks old but already the difference of good organisation, coordination, and also non-violent ways of working are palpable. There is not the menace of violence from the state that we had experienced in Calais, nor the overweening control. Children ride around on bikes everywhere; there is laughter and conversation. As we walk up and down and round the camp, people come up to us and ask us questions, request items, or tell us of their situation. Food, tea, and coffee are supplied, and we stand in the sunshine with a bag of salted sunflowers sharing them with a man from Iran. In Farsi, Turkish, some Arabic, and broken English we hold a conversation - one about hope and despair - not about the conditions in the camp but the politics of refugees in Europe. 'Where to, when no one will take you? Where to?' And I hear again the question asked by Jews fleeing Nazi Germany. And I hear the same answers: 'Not here, not here, not to us.'

Ninety per cent of the camp inhabitants are Kurds. There are many young men dying inside of frustration. They invite us to a meeting and tell us of Kurdistan, its history, the British involvement, the way lines were drawn on the map. They are begging the politicians to act. They are gracious, courteous; they arrange translation and greet us formally. Then the stories begin and I recognize them as those I have also heard from other desperate nations without states from the Palestinians. The litany of historical events that must be recited carefully and correctly so that the audience understands the seriousness of the situa- 
tion. The locations and sources of siege and suffering - Kirkuk; Dayesh. I realize that those speaking with such focus and careful urgency are desperate to find a way of telling the story, the epic story of their suffering, in a way that will communicate sufficiently that their suffering will end - for their suffering is intolerable and inhuman, and they cannot believe that it is one human beings can allow. So, the logic goes, there must be a way of telling the story, of giving testimony to those who bear witness, that will work, that will end the suffering. They try every angle. And I realize how I am utterly confounded, for there is not a way of communicating this story to those with power. I watch as those who are elected representatives in one of the richest countries in the world, bear the weight of witnessing and the individual responsibility which comes with their offices, to act, but in a Parliamentary democratic context where they can already see how hard it will be to bring even one of those asking for resettlement, to the UK. For all we are in the presence of politicians with real power who are determined to advocate and act, the kind of simple request for sanctuary has become unbearably complicated and difficult to address.

There is utter despair and suicidal hopelessness in the eyes of one of the men. I understand it. I have no words.

In Calais we had met a man who had known this despair and overcome it and learned to live from day to day with no hope. He said, 'I know there is nothing you can do. But it is enough that you have come to say hello to us.'

There is nothing we can do. Those with the power to make the physical camp conditions better have done it and done it courageously and in a way which contrasts completely with the simultaneous destruction of the camps. So here we are, one human being with another, individuals witnessing and bearing responsibility, in the state of exception that is the refugee camp in Europe in 2016, and we are united in a common understanding of the hopelessness of it all and thrown back on the most basic of human activities - that of the giving and receiving of hospitality, of meeting, greeting, and eating together. As we leave the camp, many of those with whom we had shared conversations accompanied us, giving us a written message and waiting until our rides back had arrived and waved goodbye. Europe 2016.

Calais, Day 4: It's our last day and time for a long, serious, and sustaining meeting with MSF workers about camp conditions, about the violence, sanitation, legal advice, the place of politics, well-being of volunteers, and what on earth can be done. It's time for commitments.

First-hand reports of random use by French riot police overnight of 500 tear gas canisters on the camp in Calais and of a young man from the camp crushed to death under a lorry. 
At Calais-Fréthun, the Eurostar station, there is the presence of handguns with customs officers and of dogs as well as sub-machine guns - all part of the menacing atmosphere of the threat of state intervention under state of emergency powers.

The whole group is engaged in careful, considered discussion of what might be actions and how to create a future where the shame and impossible despair and entrapment of the camps is replaced by just futures and humane possibilities.

However well managed and constructed a camp, it is no solution, and certainly not a semi-permanent one. They are places of slow killing of body, mind, and spirit. To all intents and purposes they are death camps.

\section{Bearing the witnessing}

In her memoir (unpublished) and $\mathrm{PhD}$ thesis reflecting on the ecological disaster that is climate change, Sarah Thomas turns to Ursula Le Guin's writings on nature to consider the kinds of change wrought by metaphorical usages and emphasises: 'I am struck by how much we talk about rebirthing but never about rebearing... A door opens just by changing the name. We don't have to be reborn; we can rebear. This is part of the writer's job, either to rebear metaphors or refuse to use them' (Le Guin 1994, 107).

I have lived within the witness-bearing space with people seeking refuge for at least fifteen years. It was a choice and a commitment and a compulsion. It is a responsibility and at some level about both obeying the laws of motion and upholding the spirit and letter of international law, of the conventions and articles which give us protection. As an academic, this witness-bearing space is shaped and changed by artistry, advocacy, theory, and practice. It is linguistic and intercultural and fraught. It is also constantly in need of 'rebearing' in the sense that at times it can be light, feather-like, drifting on the breeze, it is joyous and optimistic and redolent with the ease that is responsibility satisfied, witnessing borne with and borne well. But it also needs to be borne in a heavier sense. It needs to find minds and bodies and souls which can hold it, especially when others cannot, or when respite is needed, or when the journey as stalled and stasis prevents any movement. The question posed at the outset here changes with an emphasis on the idea of 'bearing with', it moves it from the snapshot of the shutter click of Sontag's photography to the sustained temporalities of a narrative. 'Can you bear this witness?' as opposed to 'Will you bear witness?' is not a legal question of the subject but a question of tenacity, temporality, and faithfulness to the human being. 
Bearing the witness of Calais, with its ongoing responsibilities and the ongoing bearing with the witness which began there, has had many consequences which bleed into my academic life and out again into my life as a subject. Philosopher and psychoanalyst Luce Irigaray makes an injunction to women to never abandon subjective experience as an element of knowledge (Irigaray 1994). The witness-bearing work in Calais did not last just a few days but has continued in both proximity and distance. The writing continues the witness, I meet unaccompanied minors resettled here in Scotland and support their families. My own foster daughter was in the Calais camps over ten years ago. I work with poets and photographers in their documenting of camp life, with academics, with NGOs developing resource materials, with lobbying groups trying to bring a change in UK law and policy.

The camp has closed, violently. The situation in the Pas-de-Calais is absolutely desperate. Reports reach me almost daily of NGOs at their wits' end as French and European policy tightens the noose around those who would dare to pose the question of sanctuary with their presence on European soil.

Bearing witness has brought me up sharp against my own limits, not least those as an academic but also as an activist and advocate. Bearing witness has not brought change, or very little it seems; the presence of powerful lawmakers and experts at witnessing did not prevent the violent destruction of the camp or the changing of policy in the UK government. For all the excellent, heartfelt, and expert witness speeches, the efforts were frustrated again and again. When some children were resettled, the press seized upon this as an opportunity to take photographs and question the age of the minors. More experts - dentists, paediatricians, teachers - were brought in to speak into a fraught public debate, that has lost all semblance of having ethical bearings.

Bearings. Bearing. One of things that happens in bearing witness to the treatment of people seeking asylum is that you lose you bearings. The laws you grew up with in Europe, the conventions and articles protecting freedom of movement and the right to claim asylum have been so chopped about with so-called arrangements for burden-sharing, and Dublin conventions, and the movement and fixing of certain bodies in certain places, preferably on the peripheries of Europe, that it's hard to trust to the Rule of Law and the International Articles in the long term, even though there is ample evidence that they have helped save lives and are one of our most reliable instruments of justice. There is a look about us, those of us who have been here for a long time, bearing with this, bearing this allies and refugee actors alike - a grim and often smiling knowing that helps with the shouldering of the load. 


\section{Coda: The tradition of bearing}

In the Western tradition, there is a story of a man who was pulled out of a crowd at a trial and execution and asked, when the prisoner was too weak, to carry his burden. It's a story which has entered into language in the idiom of resilience, and of distress: 'carry your cross'.

\section{Friday - Hearkening}

The story tells us

he was from a big city some distance away

and he was there;

and he did not say I cannot carry this

and he did not say I do not want the skelfs in my skin

and he did not say I do not have the strength

and he did not say I don't want to do this

and he did not say I will not travel with you

and he did not say I am afraid

and he did not say that the wood was sticky with your blood

and he did not say I despise you

and he did not say I do not want your shame upon my back

and he did not say he would not dig deep to find the strength

and he did not say his own suffering was great too

and he did not point first to his own burden

and he did not say that this was far too messy

and he did not say he was too good for the task

and he did not argue

and he did not ask why

and he did not say I do not want your suffering near me

and he did not say his kind did not help your kind

and he did not say that you should say sorry

and he did not say that you should be more careful

and he did not judge

and he did not hide his name

and he did not hide his home

and his name was Simon,

meaning hearkening, listening

and he was there 
and he walked the way

and he carried it for a while.

And he was there.

And that is the story.

And that is all.

\section{Bibliography}

Arendt, H. (1943): We Refugees. In: Menorah Journal 31(1), 69-77.

Butler, J. (2011): Precarious Life: The Obligations of Proximity. Neale Wheeler Watson Lecture.

24 May. Nobel Museum, Svenska Akademiens Börssal.

Choo, A. (2015): Evidence. Oxford, Oxford University Press.

Dennis, I. H. (2017): The Law of Evidence. London: Sweet \& Maxwell.

Haraway, D. (2016): Staying with the Trouble: Making Kin in the Chrhulucene. Durham: Duke University Press.

Irigaray, L. (1994): Thinking the Difference: For a Peaceful Revolution. London: Athlone.

Le Guin, U. (1994): Crossing Back from the Silence. In: J. White (ed.): Talking on the Water: Conversations about Nature and Creativity. San Franscisco: Sierra Club Books.

McFague, S. (1975): Speaking in Parables: A study in Metaphor and Theology. London: SCM Press.

Myers, A. (2016): Nothing Is Impossible Under the Sun. Sweden/Scotland: Sound of a Picture.

Phipps, A. (2017): Why Cultural Work with Refugees? E.P.C.o.C.a. Education. Brussels, European Union.

Piacentini, T. (2014): Missing from the Picture? Migrant and Refugee Community Organizations' Responses to Poverty and Destitution in Glasgow. In: Community Development Journal.

Scarry, E. (2010): Rule of Law, Misrule of Men. Boston: MIT Press.

Sontag, Susan (2004): Regarding the Pain of Others. New York: Picador.

Turner, V. (1995): The Ritual Process: Structure and Anti-Structure. New York: De Gruyter. 